\title{
Penggunaan kata umpatan di Twitter berdasarkan gender di pilkada Sumatera Utara 2018
}

\author{
Likha Sari Anggreni ${ }^{1}$, Rino Ardhian Nugroho ${ }^{2}$, Haniefira Safantyarizka Luthfi ${ }^{3}$, \\ Indriana Mega Kresna ${ }^{4}$, dan Teguh Budi Santoso ${ }^{5}$ \\ 1,2,3,4,5 Universitas Sebelas Maret, Solo, Indonesia
}

\begin{abstract}
ABSTRAK
Di dalam pandangan tradisional, perempuan distigmatisasi menjadi lemah lembut dan anggun. Oleh karena itu, sangat jarang kita melihat perempuan mengatakan kata kasar di ruang publik karena tabu bagi mereka. Media sosial menyediakan ruang virtual bagi orang untuk berinteraksi tanpa batas yang jelas. Orang-orang di Internet (netizen) dapat mengatakan hampir semuanya di media sosial tanpa memikirkan dampak negatif pada apa yang mereka katakan. Beberapa netizen melewati batas kesusilaan dengan mengucapkan kata kasar kepada netizen lain tanpa berpikir yang mungkin menyakiti seseorang. Studi terbaru menunjukkan bahwa kata-kata kasar dapat menyebabkan cyberbully yang pada akhirnya akan mengarah ke bunuh diri. Dengan demikian menggunakan kata kasar di media sosial mungkin memiliki dampak yang sama dengan menggunakannya dalam kehidupan nyata. Kemajuan media sosial telah menyebabkan penggunaannya dalam politik praktis. Kandidat politik menggunakan media sosial untuk mempromosikan profil mereka dan akhirnya mendapatkan pemilih. Sayangnya tidak semua dari mereka yang memposting komentar di media sosial beretika, termasuk perempuan. Penelitian ini bertujuan untuk mengkaji pemanfaatan Twitter dalam mengeluarkan kata umpatan berdasarkan perbedaan gender dalam pemilihan gubernur. Penelitian ini akan menganalisis Twitter sebagai platform media sosial paling umum yang digunakan dalam politik. Sebagai contoh, penelitian ini menangkap 5000 tweet dari pemilihan pilkada Sumatera Utara 2018 di Indonesia. Teknik statistik deskriptif digunakan dalam menganalisis data.
\end{abstract}

Kata-kata Kunci: gender; gubernur; kata umpatan; pilkada 2018; Twitter

\section{Gender differences and the use of harsh word on Twitter In North Sumatra election 2018}

\begin{abstract}
In traditional viewpoints, women are stigmatized to be soft and graceful. Therefore, very rare we would see women saying harsh word in the public space as it is taboo for them. Social media provides a virtual room for people to interact without clear boundary. People on the Internet (netizen) can say almost everything in social media without thinking about the negative impact on what they were saying. Some of the netizen passing the decency by saying harsh word to other netizen without thinking that might hurt someone. Recent studies indicated that harsh words may lead to cyberbully that eventually will lead to suicide. Thus using harsh word in social media might have similar impact with using it in the real life. The advancement of social media has led to the use of it in the practical politics. Political candidates use social media to promote their profile and eventually gain voters. Unfortunately not all of them were posting an ethical comment on the social media, including women. This study aims to analyse Twitter usage gender differences in using hars word in governor election. This study will analyse Twitter as the most common social media platform that were used in politics. As the sample this study captured 5000 tweets from the 2018 North Sumatra election in Indonesia. A descriptive statistics technique was used in analysing the data, Further implication is discussed in the paper.
\end{abstract}

Keywords: gender; governor; governor election 2018; harsh word; Twitter

Korespondensi: Likha Sari Anggreni, S.Sos., M.Soc.Sc. Universitas Sebelas Maret. Jl. Ir. Sutami No. 36A Kentingan Surakarta Jateng. Email: likhasari@staff.uns.ac.id.

Submitted: May 2018, Accepted: December 2018, Published: June 2019

ISSN: 2303-2006 (print), ISSN: 2477-5606 (online). Website: http://jurnal.unpad.ac.id/jkk

Terakreditasi Kemenristekdikti RI SK No. 48a/E/KPT/2017 


\section{PENDAHULUAN}

Pemberitaan hoax dewasa ini semakin mudah dan sering ditemui di media baru, terutama pada pemberitaan online dan media sosial. Orang dengan mudah mendapatkan berita hoax yang kemudian membagikan berita tersebut kepada orang lain melalui akun media sosialnya. (Allcott \& Gentzkow, 2017) mendefinisikan berita hoax sebagai artikel berita yang disengaja dan dibuktikan salah dan bisa menyesatkan pembaca. Sedangkan Rasywir dan Purwarianti (2015) menjelaskan bahwa hoax merupakan informasi sesat dan berbahaya karena menyesatkan persepsi manusia dengan menyampaikan informasi palsu sebagai kebenaran. Dengan penyebaran berita hoax tersebut maka dapat mengakibatkan kesalahpahaman pada informasi tertentu.

Akibat dari adanya pemberitaan hoax, muncul tanggapan dari warga di Internet (netizen). Tidak sedikit netizen memberikan komentar negatif yang kemudian muncul ujaran kebencian yang disampaikan melalui akun media sosial. Netizen dengan mudah menuliskan pada ruang komentar di medium ini. Sebuah kajian yang dilakukan oleh Gagliardone, Gal, Alves, \& Martinez (2015) menyebutkan bahwa fenomena ujaran kebencian secara online semakin berkembang dan menimbulkan beragam masalah. Disebutkan pula oleh Gagliardone dkk. (2015) bahwa ujaran kebencian melalui media online sudah semakin pesat dan memiliki potensi untuk mencapai audiens yang lebih besar. Kemudian dijelaskan pula oleh Juditha (2017) bahwa ujaran kebencian dalam isi komentar berita menunjukkan bahwa semua pasangan calon pada pilkada dikomentari netizen, dengan tema komentar dominan mengarah pada kebencian terhadap agama dan SARA yang pada pilihan Gubernur Jakarta pada 2017.

Kata kasar atau umpatan merupakan bagian dari ujaran kebencian. Mengumpat merupakan fenomena linguistik yang seringkali ditampilkan dalam berbagai media seperti majalah, koran, iklan, dan film. Walaupun sering ditemukan, sampai saat ini mengumpat masih menjadi hal yang tabu dan dianggap tidak sesuai dengan norma yang berlaku di masyarakat.

Umpatan sering dijadikan sebagai pelengkap ketika percakapan berlangsung. Pada percakapan, seringkali umpatan disisipkan sebagai pelengkap kata, namun hal ini dianggap tidak baik karena seharusnya ketika berbicara sebaiknya komunikan memberikan kesan baik pada lawan bicara. Umpatan biasanya digunakan saat percakapan informal oleh seseorang untuk mengekpresikan perasaan dan meluapkan emosi. Tak jarang, kata-kata umpatan juga dipakai untuk menyakiti perasaan seseorang saat emosi sudah mencapai puncak. Bagi sebagian kelompok, umpatan dianggap sebagai bahasa solidaritas maupun identitas yang dipakai untuk berkomunikasi antar anggota kelompok.

Pada penelitian yang dilakukan oleh Putra (2012) ada beberapa bentuk umpatan yang biasa digunakan dalam berkomunikasi, yaitu: (1) umpatan yang menggunakan nama-nama hewan; (2) umpatan yang menggunakan anggota tubuh; (3) umpatan berjenis kata profesi; (4) umpatan berjenis aktivitas; (5) umpatan berjenis kata sifat; (6) umpatan berjenis makhluk halus; (7) umpatan berjenis kata kekerabatan; (8) umpatan berjenis kata benda; (9) umpatan berjenis makanan; (10) umpatan dalam bahasa asing.

Rosidin (2010) menyatakan bahwa terdapat tiga syarat agar suatu kata atau ungkapan dapat dikelompokkan sebagai kata umpatan, yaitu: (1) Merujuk pada tabu atau stigma (tanda dari ketidak berterimaan sosial dalam suatu lingkungan budaya); (2) tidak dapat ditafsirkan secara harfiah; (3) dapat digunakan untuk mewujudkan emosi dan sikap yang kuat. Dua pernyataan tersebut menjelaskan kriteria sebuah kata bisa dinyatakan sebagai umpatan. Kriteriakriteria tersebut digunakan sebagai dasar dalam menentukan kriteria umpatan yang dianalisa dalam penelitian ini.

Kata kasar/umpatan yang ditampilkan di media sosial seringkali dimanfaatkan oleh para kontestan dalam kegiatan politik seperti pemilihan presiden, gubernur dan bupati/ walikota. Penggunaan media sosial ini mafhum digunakan karena Twitter dianggap mampu menjalin hubungan yang lebih erat dengan para pemilih/calon pemilihnya dibandingkan dengan media mainstream (Bode \& Dalrymple, 2016). Studi literatur terdahulu menunjukkan peran Twitter dalam politik di berbagai negara dengan berbagai variasi, mulai dari penggunaan untuk memperkenalkan calon, ajakan memilih calon hingga debat online antar pendukung calon (Jungherr, 2014).

Penelitian yang dilakukan di Malaysia 
sebagai negara yang memiliki kemiripan karakter dengan Indonesia juga menunjukkan bahwa Twitter memiliki peran penting dalam pemilihan umum (Kasmani, Sabran, \& Ramle, 2014). Twitter adalah salah satu media sosial yang memungkinkan penggunanya untuk mengirim dan membaca pesan singkat berbasis teks sejumlah maksimal 280 karakter. Twitter memiliki daya tarik sehingga penggunanya merasa bebas mengekspresikan diri tanpa takut dan berpikir lebih panjang untuk mempublikasikannya ke khalayak. Karena hal tersebut, tak jarang pengguna yang sedang meledak-ledak emosinya jadi menuliskan katakata umpatan atau makian. Hal ini sejalan dengan temuan Kiesler, Siegel, \& McGuire (1984) yang menemukan bahwa komunikasi yang dimediasi oleh komputer apapun bentuknya akan mengurangi norma sosial yang biasanya ada dalam komunikasi verbal secara langsung, termasuk di dalamnya kata umpatan.

Twitter memungkinkan penggunanya untuk berinteraksi dengan orang lain yang memiliki latar belakang berbeda dan tidak mengenal satu sama lain pada kehidupan nyata. Dengan keadaan yang seperti itu tidak mengherankan apabila di Twitter seseorang akan berbeda dengan aslinya. Perempuan yang seringkali dicitrakan sebagai sosok yang lembut dalam kehidupan sehari-hari bisa berubah di akun sosial media ini. Sebagaimana diutarakan dalam penelitian di Inggris dimana kini makin sering dijumpai kata umpatan diucapkan oleh perempuan di Twitter (Gauthier, Guille, Rico, \& Deseille, 2015).

Fakta-fakta ini menunjukkan adanya pergeseran makna peran berdasarkan gender dengan adanya kemajuan teknologi. Sejauh ini perempuan acapkali digambarkan sebagai sosok yang lembut dan banyak berurusan dengan pekerjaan rumah. Teori peran sosial (Eagly, 1987) mengidentifikasi perbedaan antara peran sosial perempuan dan laki-laki dalam masyarakat. Sebagai contoh, perempuan memiliki peran domestik dan mengurus anak, sedangkan laki-laki berperan sebagai sosok yang mendukung finansial keluarga. Pembagian peran gender yang diharapkan bisa saling melengkapi ini mencakup lintas waktu dan generasi serta berdampak pada perilaku sosial masing-masing jenis kelamin (Eagly, 1987, 1997; Eagly, Wood, \& Diekman, 2000). Teori peran sosial menyatakan bahwa peran sosial yang berbeda dari laki-laki dan perempuan adalah dasar bagi perbedaan dalam apa yang pria dan perempuan cari dalam mitra jangka panjang (Eagly, Eastwick, \& JohannesenSchmidt, 2009).

Sebuah studi yang dilakukan oleh Bekir dkk. (2014) menyatakan apabila terlihat bahwa ada suasana berbagi dalam pekerjaan rumah tangga, partisipasi dalam pengambilan keputusan dan perkembangan dalam pasangan patriarkal dan hubungan tradisional yang terbentuk satu sama lain tetapi pembagian kerja berbasis gender masih berlanjut, dan pekerjaan rumah tangga umumnya dilakukan oleh perempuan. Keputusan yang terkait dengan rumah umumnya ditentukan oleh perempuan, tetapi keputusan lain (mengenai pilihan rumah, liburan atau hiburan) umumnya diambil oleh laki-laki. Singkatnya, dalam masyarakat kita struktur laki-laki yang dominan masih terus berlanjut dan perempuan yang mengalami kekerasan dalam rumah menyembunyikannya dari keluarga mereka dan bahkan menerimanya sebagai tindakan yang sah dan dalam proses pengambilan keputusan mereka, perempuan cenderung tidak berpartisipasi. Terdapat kemungkinan bahwa pria menerima perempuan sebagai seseorang yang melakukan pekerjaan rumah tangga, membesarkan anak-anak atau memenuhi kebutuhan seksual pria dan cara berpikir ini melewati beberapa generasi. Perbedaan cara pandang dan pergeseran tentang kesetaraan gender ini menurut penelitian dipengaruhi oleh antara lain: kondisi ekonomi, faktor budaya, dan bawaan sejak lahir (Jayachandran, 2015).

Pendidikan dan teknologi ikut andil dalam pergeseran kesetaraan gender. Di era ini, perempuan lebih berani melakukan pergerakan dan leluasa dalam pembuatan keputusan untuk dirinya sendiri. Ekspresi atas kebebasan terhadap dirinya sendiri adalah semakin beraninya kaum perempuan untuk tampil dan menyuarakan apa yang menjadi pendapatnya di sosial media, termasuk di bidang politik. Kandidat gubernur di Amerika Serikat baik laki-laki maupun perempuan menggunakan sosial media untuk menyuarakan pendapatnya dengan cara yang berbeda, laki-laki cenderung lebih memanfaatkan pencitraan melalui sosial media dibandingkan perempuan (McGregor, Lawrence, \& Cardona, 2017).

Kemajuan di bidang kesetaraan gender dan 
politik itu memberikan kemajuan yang positif, misalnya penelitian menunjukkan potensi media sosial untuk menantang dominasi laki-laki di bidang politik (Demirhan \& Çakır-Demirhan, 2015) dan mengubah demokrasi supaya lebih memberikan peran kepada perempuan (Radsch \& Khamis, 2013).

Meskipun demikian di pemanfaatan media sosial untuk kesetaraan gender tidak selalu bermanfaat secara positif. Dampak negatif dari kemajuan teknologi, khususnya pemanfaatan media sosial dalam sikap politik adalah penggunaan media sosial untuk menghina orang lain yang berseberangan pandangan politik (Abril, 2016) atau membanggakan diri sendiri secara berlebihan (narscism) untuk kepentingan politik diri sendiri (Preotiuc-Pietro, Carpenter, Giorgi, \& Ungar, 2016).

Kegiatan pilihan gubernur di Indonesia tahun 2018 ini dilakukan berdasarkan pertimbangan dari beberapa ahli politik. Berangkat dari UU No.12 Tahun 2013 tentang Pemilu menyebutkan bahwa Pemilu merupakan sarana pelaksanaan kedaulatan rakyat dalam Negara Kesatuan Republik Indonesia yang berdasarkan Pancasila dan UUD 1945 dengan berasaskan LUBERJUDIL. Pemilu ini dilakukan dengan tujuan untuk memilih wakil rakyat dan wakil daerah. Dalam pelaksanaan pemilihan gubernur terdapat tiga opsi yang ditawarkan, pertama, gubernur dilihih oleh DPRD, kedia, gubernur dipilih langsung oleh rakyat, ketiga, gubernur ditunjuk oleh presiden (Nugraha, 2017). Pemilihan raya kepala daerah pertama kali dilakakukan pada tahun 2005, kemudian menjadikan Indonesia menjadi demokratisasi dan desentralisasi. Namun proses pemilihannya masih belum dipilih langsung oleh rakyat, melainkan melalui pemilihan oleh DPRD. Kemudian tahun 2014 muncul PP UU No.1 th 2014 tentang Pemilihan Gubernur, Bupati dan Walikota bahwa kepala daerah akan dipilih langsung oleh rakyat melalui pemilu (Hardjaloka, 2015). Pada tahun 2015, pemerintah mulai menyinkronkan jadwal pemilihan supaya tidak dilakukan secara mandiri di masing-masing daerah. Pada bulan Februari 2017 terdapat 101 jadwal dan Juni 2019 171 jadwal (Pemilihan Gubernur di Sumatera Utara dilakukan pada waktu ini). (Aspinall \& Mas'udi, 2017).

Selain kegiatan politik yang erat dengan kampanye dan pemilihan kandidat pimpinan daerah/negara, Twitter juga dapat digunakan untuk melihat pandangan politik warga terhadap isu tertentu. Pada isu pengungsi misalnya, Twitter dapat memetakan bagaimana perbedaan pandangan politik antara warga Inggris dan Turki dalam menyikapi pengungsi Syria yang memasuki negaranya. Dimana warga Inggris cenderung memiliki pandangan negatif dibandingkan warga Turki dalam menyikapi masuknya pengungsi Syria ke negara mereka (Öztürk \& Ayvaz, 2018)

Dua penelitian tersebut menunjukkanbahwa Twitter dapat digunakan untuk memahami kegiatan politik di dunia nyata. Penelitian lain menemukan bahwa ada kaitan antara jenis kelamin (gender) dan perilaku politiknya di media sosial. Sebuah penelitian menunjukkan bahwa pengguna Twitter yang memanfaatkan media sosial tersebut untuk kegiatan politik didominasi oleh laki-laki (Barberá \& Rivero, 2015). Penelitian lain juga menunjukkan bahwa Twitter lebih sering digunakan untuk menyerang lawan politik oleh politisi lak-laki dibandingkan perempuan (Bode, 2017).

Penelitian ini dilakukan untuk mengkaji pemanfaatan Twitter dalam mengeluarkan kata umpatan berdasarkan perbedaan gender. Temuan sebelumnya menyatakan bahwa Twitter acapkali digunakan untuk pergerakan politik praktis di Indonesia (Wibowo \& Mirawati, 2013) yang salah satunya digunakan sebagai media untuk pemenangan pilihan presiden 2014 (Senova, 2016).

Pengetahuan tentang hal ini akan memberikan pemahaman baru tentang pemanfaatan media sosial pada kontestasi politik di Indonesia, sekaligus menggambarkan bagaimana perbedaan gender mempengaruhi perilaku politik mereka di media sosial. Sebagai studi kasus penelitian ini menggunakan pemilihan Gubernur Sumatera Utara, Indonesia sebagai unit analisisnya. Wilayah ini dipilih karena berdasarkan analisa yang dilakukan oleh salah satu media televisi ternama di Indonesia, wilayah ini merupakan wilayah yang paling panas dalam perang media sosial (Metrotvnews, 2018).

\section{METODE PENELITIAN}

Studi ini menggunakan pendekatan penelitian kualitatif yaitu penelitian yang mengumpulkan data kualitatif untuk 
menggambarkan rincian tentang manusia, tindakan dan peristiwa dalam kehidupan sosial (Neuman, 2016). Objek penelitian pada studi ini adalah perbincangan di media sosial Twitter terkait pemilihan kepala daerah di Provinsi Sumatera Utara (Pilkada Sumut), Indonesia. Penelitian ini dilakukan pada saat pemilihan kepala daerah serentak di Indonesia yang terjadi pada tanggal 27 Juni 2018. Lokasi dari penelitian ini adalah di media sosial Twitter dengan periode pengambilan data dimulai dari 22 Juni sampai dengan 28 Juni 2018

Penelitian dilakukan dengan menggunakan dua tahap pendekatan kualitatif. Tahap pertama penelitian dilakukan dengan menggunakan metode analisis isi (content analysis) lalu tahap kedua penelitian dilakukan dengan menggunakan metode analisis domain (domain analysis). Analisis isi dilakukan dengan dengan menghitung secara kuantitatif kata-kata tertentu (Neuman, 2016; McNabb, 2015). Pada penelitian ini kata-kata yang dihitung adalah kata-kata umpatan yang diperoleh dari media sosial Twitter berkaitan dengan Pilkada Sumut. Model analisis ini sudah dibuktikan mampu memberikan gambaran perbedaan gender di Twitter (Parmelee, Roman, Beasley \& Perkins, 2019) dan tepat untuk mengklasifikasikan komentar di Twitter (Williams, Terras \& Walwick, 2013).

Analisis domain dilakukan dengan cara membaca berulang-ulang temuan data kualitatif, mencari hubungan diantaranya lalu mengkaitkan konsep-konsep yang terhubung dengan tema tertentu yang serupa (Neuman, 2016). Analisis ini tepat digunakan untuk menggali data di Twitter sebagaimana dicontohkan pada penelitian sebelumnya (Shahheidari, Dong \& Daud, 2013). Pada penelitian ini analisis domain dilakukan dengan mengelompokkan kata-kata umpatan yang ditemukan dalam Twitter pada pilkada Sumut 2018. Adapun sebagaimana sudah diutarakan sebelumnya pengelompokan domain umpatan akan disesuaikan dengan tipetipe umpatan yang sudah pernah ditemukan oleh (Putra (2012) yaitu berupa: (1) umpatan yang menggunakan nama-nama hewan; (2) umpatan yang menggunakan anggota tubuh; (3) umpatan berjenis kata profesi; (4) umpatan berjenis aktivitas; (5) umpatan berjenis kata sifat; (6) umpatan berjenis makhluk halus; (7) umpatan berjenis kata kekerabatan; (8) umpatan berjenis kata benda; (9) umpatan berjenis makanan; (10) umpatan dalam bahasa asing.

Responden yang dipilih pada studi ini adalah pengguna Twitter (tweeps) yang aktif men-tweet. Tentang Pilkada Sumut 2018. Oleh karena itu teknik sampel yang digunakan pada studi ini adalah convenience sampling, yaitu sampling dengan cara memilih data yang tersedia (Bryman, 2016). Data yang tersedia dalam penelitian ini adalah data yang diperoleh dengan cara mengambil data teks dari Twitter.

Pengumpulan data dalam penelitian ini menggunakan software analisis bernama Netlytic yang dikembangkan oleh Gruzd (2016). Netlytic adalah platform software online berbasis cloud yang berfungsi untuk melakukan analisis teks serta pola jaringan sosial dalam sosial media. Platform ini dapat secara otomatis mengumpulkan data, menyimpulkan dan menemukan pola komunikasi yang ada dalam sebuah sosial media, ketiga hal tersebut dilakukan dengan menggunakan API (Antarmuka Pemrograman Aplikasi) dari sosial media tersebut. Pencarian data menggunakan platform ini dapat digunakan ke beberapa sosial media seperti Twitter, Facebook, YouTube, dan Instagram.

Pada penelitian kali ini, peneliti menggunakan Netlytic untuk mendapatkan data di Twitter sebelum dan sesudah Pilkada serentak di Indonesia yang berlangsung pada tanggal 27 Juni 2018. Daerah yang diteliti pola komunikasinya pada penelitian kali ini adalah Sumatra Utara, karena berdasarkan beberapa berita dan laporan Pilkada Sumatra Utara diperkirakan akan berlangsung panas, sebagaimana sudah dijelaskan pada bagian akhir pendahuluan di atas.

Pencarian data dilakukan mulai tanggal 22 Juni 2018 sampai 28 Juni 2018, kata kunci yang digunakan dalam pencarian ini adalah singkatan dari masing-masing pasangan calon. Edy Rahmayadi - Musa Rajekshah dengan Eramas dan Djarot Saiful Hidayat-Sihar Sitorus dengan singkatan Djoss. Pencarian yang dilakukan tidak mengikutsertakan retweet di dalamnya untuk memperbanyak variasi dari tweet yang ada. Secara teknis kata kunci pencarian yang digunakan dalam penelitian ini adalah adalah "Eramas since: 2018-0622 until: 2018-06-28 exclude: retweets" serta "Djoss since: 2018-06-22 until: 2018-06-28 exclude: retweets". Menggunakan kedua kata kunci tersebut dihasilkan 2500 tweet dari setiap 
pasangan calon sehingga diperoleh angka total 5000 tweet dari kedua pasangan calon untuk dianalisa pada proses selanjutnya. Angka 2500 merupakan angka batasan yang bisa diperoleh melalui software Netlytics.

Penelitian ini tidak memisahkan akun Twitter yang digunakan untuk mempopulerkan pasangan tertentu atau yang disebut dengan Twitter buzzer. Ini dilakukan karena pada penelitian sebelumnya ditemukan bahwa buzzer merupakan salah satu cara yang digunakan oleh politisi untuk mendapatkan perhatian dan suara dari pemilih mereka (Kruikeimer, 2014) dan penting bagi kontestasi politik (Nulty, Theocharis, Popa, Pornet \& Benoit, 2016). Oleh karena itu dalam penelitian ini Twitter buzzer tetap dimasukkan ke dalam analisa penelitian.

\section{HASIL DAN PEMBAHASAN}

Hasil dan pembahasan ini akan dibagi menjadi beberapa bagian. Bagian pertama adalah paparan hasil penelitian yang berupa deskripsi prosedur yang sudah ditempuh untuk mendapatkan hasil tersebut. Diikuti dengan penjelasan analisis isi berdasarkan hasil data deskriptif yang sudah diperoleh dan ditutup dengan bagian ketiga yaitu analisis domain hasil penelitian yang dilakukan dengan mengklasifikasikan temuan umpatan kedalam kategori umpatan yang sudah dijelaskan sebelumnya.

Analisis dilakukan terhadap 5.000 tweet yang telah dikumpulkan menggunakan software Netlytic dengan masing-masing mendapatkan 2.500 tweet yang ditujukan kepada pasangan calon gubernur di Pilkada Sumatera Utara 2018. Dari tweet tersebut, ditemukan 239 Tweet yang memiliki kata umpatan. Hasil ini menunjukkan 4,78\% dari total tweet tentang Pilkada Sumut 2018 yang memiliki kata umpatan. Apabila dicermati lebih lanjut 239 tweet tersebut dihasilkan oleh 197 akun aktif Twitter yang ditujukan kepada pasangan calon Pilkada Sumut 2018. Setiap akun aktif Twitter tersebut bisa mempublikasi 1 sampai dengan 5 tweet bernada umpatan terhadap salah satu pasangan calon Pilkada Sumut 2018. Pada bagian berikutnya akan ditampilkan menggunakan bantuan analisa statistik deskriptif berupa diagram bulat (pie chart) tentang total umpatan yang ada di Twitter dan diikuti dengan diagram batang tentang umpatan berdasarkan perbedaan jenis kelamin. Langkah berikutnya adalah dengan menggambarkan diagram bulat total tweet yang melakukan umpatan dan dilengkapi dengan diagram batang yang menggambarkan jumlah total tweet yang melakukan umpatan berdasarkan perbedaan jenis kelamin. Langkah terakhir adalah dengan menggambarkan diagram bulat total akun Twitter yang melakukan umpatan dan dilengkapi dengan diagram batang yang menggambarkan jumlah akun Twitter yang melakukan umpatan berdasarkan jenis kelamin.

Gambar 1 menunjukkan pembagian jumlah total umpatan yang ditujukan kepada dua pasangan calon pada Pilkada Sumut 2018. Berdasarkan data tersebut tampak bahwa umpatan lebih banyak ditujukan kepada pasangan calon yang memiliki singkatan Eramas yaitu Edy Rahmayadi dan Musa Rajekshah sebesar 63\% (182 umpatan) dibandingkan pasangan calon yang memiliki singkatan Djoss yaitu Djarot Syaiful Hidayat dan Sihar Sitorus sebesar 37\% (108 umpatan).

Gambar 2 menunjukkan jumlah umpatan di Twitter pada Pilkada Sumut 2018 berdasarkan perbedaan jenis kelamin (gender). Dari grafik tersebut tampak bahwa jumlah tweet umpatan yang dituju ke Eramas didominasi oleh akun Twitter yang diduga dilakukan oleh Laki-laki (107 umpatan) dibandingkan dengan oleh Perempuan (75 umpatan). Dugaan pemilik akun ini didasarkan pada identitas akun Twitter yang diidentifikasi dari nama dan atau foto pemilik akun Twitter tersebut. Serupa dengan temuan tersebut, umpatan yang dituju ke Djoss pun lebih banyak dilakukan oleh laki-laki (56 tweet) dibandingkan oleh perempuan (52 tweet).

Grafik pada gambar 3 menunjukkan bahwa kata umpatan lebih banyak ditujukan ke Eramas sebesar 67\% (159 tweet) dibandingkan ke Djoss 33\% (67 tweet). Grafik 4 menunjukkan jumlah tweet umpatan berdasarkan jenis kelamin. Jumlah tweet umpatan terbanyak ditujukan ke Eramas yang dilakukan oleh akun bercirikan laki-laki (92 tweet) diikuti oleh umpatan ke Eramas yang dilakukan oleh akun berciri perempuan (67 tweet). Sedangkan untuk Djoss juga ada umpatan yang ditujukan kepada mereka dengan jumlah umpatan yang lebih sedikit, yaitu oleh akun berciri laki-laki (45 tweet) dana akun berciri perempuan (35 tweet).

Gambar 5 menunjukkan pembagian jumlah akun Twitter yang menuliskan tweet bernada umpatan pada Pilkada Sumut 2018. Lagi pada 


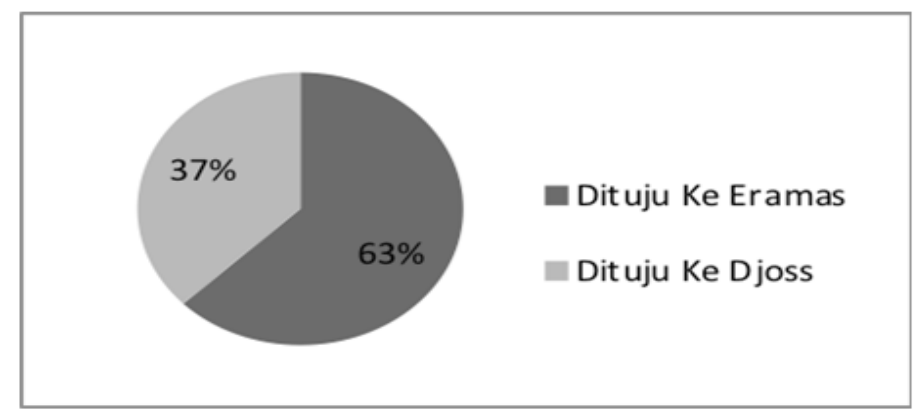

Sumber: Hasil Penelitian, 2018

Gambar 1 Jumlah Umpatan di Twitter di Pilkada Sumut 2018

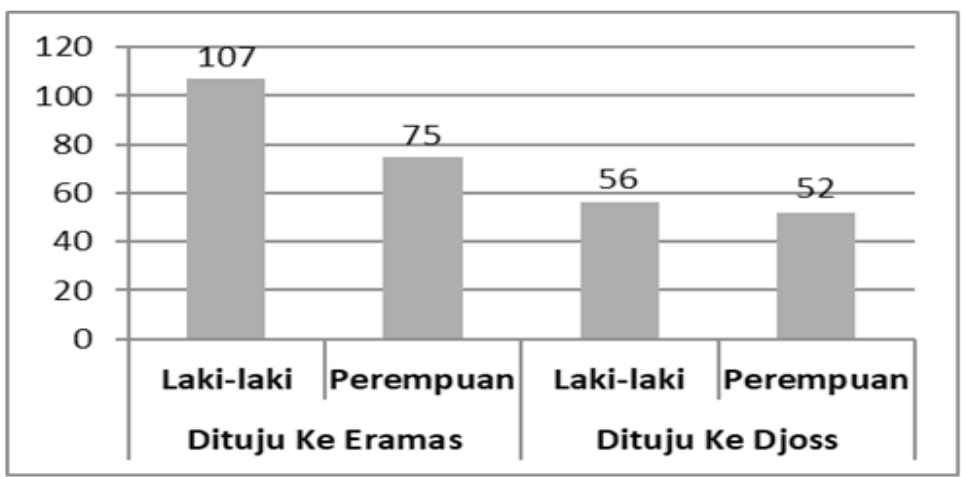

Sumber: Hasil Penelitian, 2018

Gambar 2 Jumlah Umpatan di Twitter di Pilkada Sumut 2018 Menurut Gender

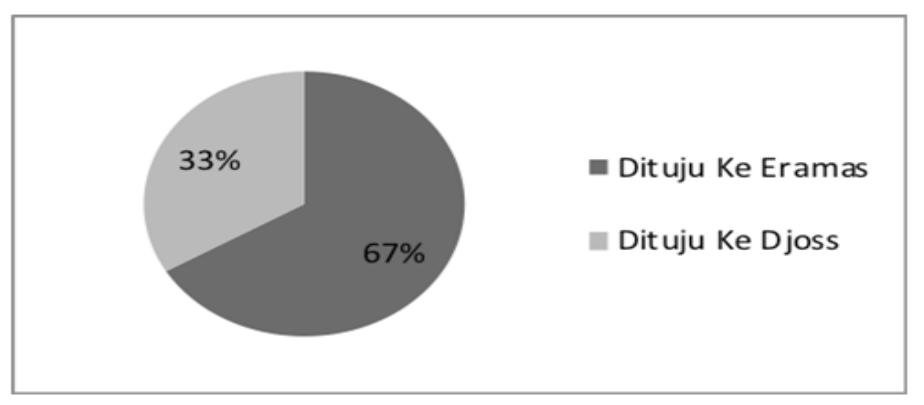

Sumber: Hasil Penelitian, 2018

Gambar 3 Jumlah Tweet Bernada Umpatan di Pilkada Sumut 2018

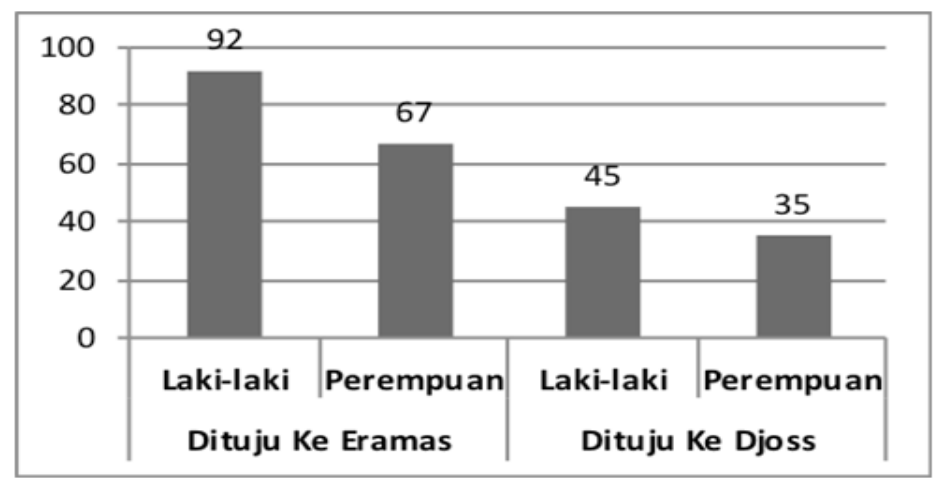

Sumber: Hasil Penelitian, 2018

Gambar 4 Jumlah Tweet Bernada Umpatan di Pilkada Sumut 2018 Menurut Gender 


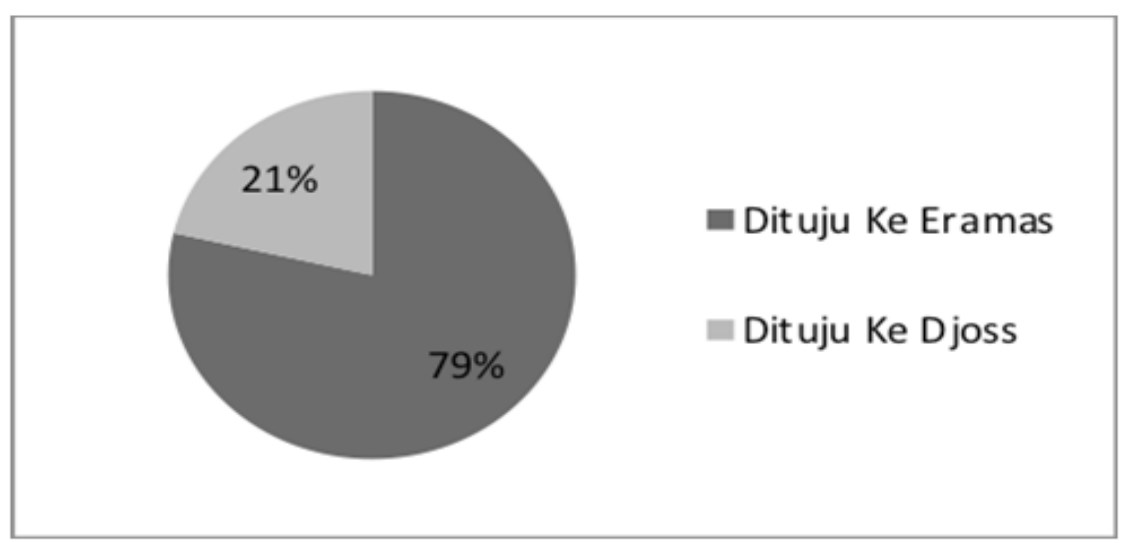

Sumber: Hasil Penelitian, 2018

Gambar 5 Jumlah Akun yang Mengumpat di Twitter Pada Pilkada Sumut 2018

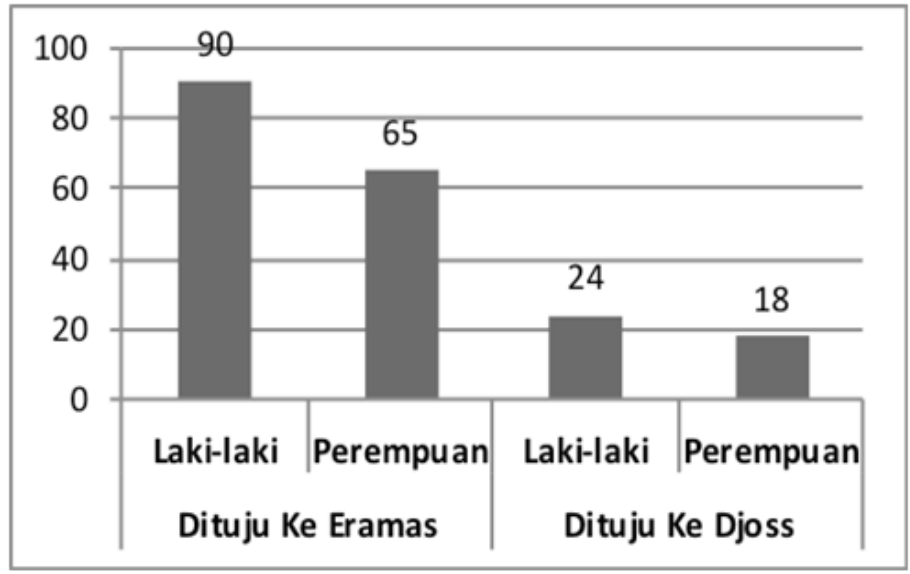

Sumber: Hasil Penelitian, 2018

\section{Gambar 6 Jumlah Akun yang Mengumpat di Twitter Pada Pilkada Sumut 2018 Menurut Gender}

kategori ini umpatan lebih banyak ditujukan ke pasangan Eramas dengan 79\% (155 tweet) dibandingkan ke pasangan Djoss dengan 21\% (42 tweet). Sedangkan untuk kategori yang sama yaitu jumlah akun yang mengumpat di Twitter dapat disimpulkan dari Gambar 6 bahwa laki-laki lebih banyak yang melakukan umpatan dibandingkan perempuan, baik untuk pasangan calon Eramas (laki-laki: 90 akun dan perempuan 65 akun) maupun untuk pasangan calon Djoss (laki-laki: 24 akun Twitter dan perempuan: 18 akun Twitter)

Berdasarkan grafik bulat dan batang dari Gambar 1 sampai dengan Gambar 6, dapat diamati beberapa hal. Pertama umpatan lebih banyak diarahkan ke salah satu pasangan calon yaitu Eramas baik untuk kategori jumlah umpatan, jumlah tweet, maupun jumlah akun Twitter yang mengumpat. Kedua dalam satu tweet bisa terdapat lebih dari satu umpatan. Ini ditunjukkan dari lebih banyaknya jumlah umpatan dibandingkan dengan jumlah tweet bernada umpatan. Salah satu contoh dari satu tweet yang memiliki lebih dari satu umpatan ditunjukkan dalam tweet yang nada umpatannya ditebalkan berikut ini:

Tabel 1 Contoh Tweet Bernada Umpatan

\begin{tabular}{|c|}
\hline "Punya Gelar Haji tapi memusuhi agama \\
sendiri. Seperti Djarot itulah pemimpin \\
MUNAFIK\#Pilgubsu2018\#Sumut\#2019Ganti \\
Presiden\#HaramPilihDjoss\#DjarotSihar\# \\
DJOSS\#HBDJokowiKerjaPakaiHati\# \\
TeenChoice"
\end{tabular}

Sumber: Hasil Penelitian, 2018

Temuan hasil pada poin pertama dan kedua di atas membuktikan bahwa penggunaan kata umpatan digunakan dalam dunia politik di Indonesia. Ini memperkaya hasil temuan sebelumnya yang berhasil menemukan 
Tabel 2 Jenis Kata Umpatan di Twitter pada Pilkada Sumut 2018

\begin{tabular}{|c|c|c|}
\hline Jenis Umpatan & Jumlah Muncul & Rincian Kata \\
\hline Kata Sifat & $30(46 \%)$ & $\begin{array}{l}\text { Abal-abal, Aneh, Angkuh, Arogan, Bar-bar, Bobrok, } \\
\text { Bodoh, Bohong/Dusta,Brengsek, Busuk, Cemen, } \\
\text { Ciut, Culas, Curang, Goblok/Bego, Haram, Haus/Gila } \\
\text { Kekuasaan, Jahat, Jijik, Kampungan, Kasar, Kisruh, } \\
\text { Konyol, Mental Kalah, Munafik/Muna, Ngaco, Palsu, } \\
\text { Rakus, Seram/Menyeramkan, Ulok (Licik-bahasa daerah) }\end{array}$ \\
\hline Kata Benda & $23(35 \%)$ & $\begin{array}{c}\text { Begundal, Bahaya, Bajingan, Banci/Bencong, Calon Napi, } \\
\text { Idiot, Intimidasi, Kafir, Kelicikan, Korupsi, Koruptor, Kata } \\
\text { Benda, Onar, Pecundang, Pengacau, Pengecut, Penipu, } \\
\text { Penista Agama, Penyamun, Perusak, Preman/Premanisme, } \\
\text { Teror, Tukang Fitnah }\end{array}$ \\
\hline Kata Kerja & $6(9 \%)$ & $\begin{array}{c}\text { Diperalat, Memecah Belah, Mengadu Domba, Ngawur, } \\
\text { Perusuh, Tidak Bermartabat }\end{array}$ \\
\hline Nama Hewan & $3(5 \%)$ & Anjing, Kampret, Monster \\
\hline Bahasa Asing & $2(3 \%)$ & $\operatorname{Fak}(F u c k)$, Hoax \\
\hline Kata Keterangan & $1(2 \%)$ & Kurang Ajar \\
\hline
\end{tabular}

Sumber: Hasil Penelitian, 2018

kata umpatan di media sosial yang acapkali dilakukan oleh pengguna Twitter dari Indonesia untuk kegiatan sehari-hari (Zulfikar, Irfan, Alam, \& Indra, 2017). Hasil ketiga yang dapat disimpulkan dari Gambar 1 sampai dengan Gambar 6 adalah akun Twitter yang bercirikan laki-laki lebih banyak melakukan umpatan dibandingkan dengan perempuan. Temuan ini sejalan dengan temuan penelitian lain yang menyatakan bahwa akun yang dicirikan dengan laki-laki memiliki kecenderungan lebih memanfaatkan media sosial dibandingkan dengan perempuan dalam hal politik (Barberá \& Rivero, 2015; Bode, 2017).

Setelah ditemukan bahwa ada kata umpatan dalam Pilkada Sumut 2018 yang didominai oleh pengguna Twitter berjenis kelamin laki-laki, maka langkah analisis yang dilakukan lebih lanjut dalam studi ini adalah melakukan analisis domain. Analisis domain dilakukan dengan cara mengklasifikasikan umpatan yang ditemukan di Twitter menggunakan 10 tema umpatan menurut Putra (2012) yaitu umpatan yang berjenis (1) nama hewan; (2) anggota tubuh; (3) profesi; (4) aktivitas; (5) kata sifat; (6) makhluk halus; (7) kata kekerabatan; (8) kata benda; (9) berjenis makanan; (10) bahasa asing.

Untuk melakukan domain analisis pertamatama setiap kata umpatan yang muncul akan diberi kode (koding) sesuai dengan 10 tema umpatan dalam bahasa Indonesia menurut Putra
(2012). Agar koding lebih akurat bahasa baku sesuai dengan kamus besar bahasa Indonesia (KBBI) digunakan. Setiap kata umpatan yang ditemukan akan di cek secara online di Kamus Besar Bahasa Indonesia yang tersedia di website https://kbbi.web.id. Ringkasan dari analisa domain ditunjukkan dalam pada Tabel 2.

Tabel 2 menunjukkan kata sifat merupakan umpatan yang paling sering digunakan di Twitter pada Pilkada Sumut 2018 denga jumlah 30 kata $(46 \%)$ dari total 65 kata-kata yang digunakan. Jenis kata umpatan yang paling sering digunakan berikutnya adalah kata benda (23 kata - 35\%), kata kerja (6 kata-9\%), nama hewan (3 kata - 5\%) dan umpatan menggunakan Bahasa asing (2 kata - 3\%). Satu kategori baru ditemukan sebagai pelengkap 10 kategori kata umpatan dari Putra (2012) yaitu umpatan berupa kata keterangan.

Jika dikaji lebih dalam berdasarkan pemisahan gender. Kata umpatan ternyata tidak hanya digunakan oleh akun Twitter yang bercirikan pengguna laki-laki, tetapi data temuan juga menunjukkan bahwa perempuan juga berani berekspresi dengan mengungkapkan kata-kata umpatan di Twitter.

Berdasarkan pengelompokan kata ditemukan bahwa kata sifat merupakan katayang paling banyak digunakan untuk mengumpat di Twitter pada Pilkada Sumut 2018. Secara rinci per kata yang muncul jika dilihat dari jenis 
kelamin yang mengutarakan dapat dijabarkan sebagai berikut. Kata kasar/umpatan yang menempati posisi teratas adalah mengatakan bahwa pasangan calon dianggap curang, sebanyak 24 Tweet, 9 diantaranya dipublikasi oleh perempuan . Di posisi kedua, bohong/dusta merupakan kata yang sering dilontarkan kepada pasangan calon, dari 21 Tweet, 11 di antaranya dipublikasi oleh perempuan. Posisi ketiga ditempati oleh kata bahaya dan preman dengan masing-masing berjumlah 11 Tweet, di mana 12 dari 22 Tweet dipublikasi oleh perempuan.

Secara ringkas perbandingan penggunaan kata kasar dalam Twitter pada Pilkada Sumut 2018 antara perempuan dan laki-laki adalah 1:3. Melalui perbandingan tersebut, laki-laki memang masih mendominasi, namun perbandingan tersebut cukup untuk membuktikan bahwa perempuan yang dinilai memiliki sifat lemah lembut juga mampu mengekspresikan diri di Twitter dengan mengeluarkan kata-kata umpatan.

\section{SIMPULAN}

Studi ini menunjukkan bahwa media sosial bisa digunakan sebagai media komunikasi politik antar pendukung pasangan calon sebuah kontestasi politik seperti pemilihan kepala daerah di Indonesia. Studi ini juga mengungkap bahwa komunikasi via media sosial tersebut tidak hanya menghasilkan kata-kata dukungan yang positif tetapi juga ada kata umpatan. Berdasarkan perbedaan gender memang masih ditemui bahwa akun Twitter dengan ciri pemilik laki-laki masih dominan dalam mengeluarkan kata umpatan jika dibandingkan dengan akun Twitter dengan ciri pemilik perempuan.

Tidak kurang dari enam jenis kata umpatan digunakan dalam studi yang mengamati perilaku di Twitter pada Pilkada Sumut 2018 ini. Enam jenis kata itu terdiri dari kata sifat, kata benda, kata kerja, nama hewan, umpatan berbahasa asing dan kata keterangan. Beragam kata umpatan tersebut digunakan oleh pengguna yang berciri laki-laki maupun perempuan.

Implikasi praktis dari penelitian ini adalah pemerintah dalam hal ini Komisi Pemilihan Umum sebaiknya memperhatikan penggunaan kata-kata kasar di sosial media dan menganggapnya sebagai pelanggaran pemilu, karena pilihan kata yang digunakan tidaklah mendidik dan bisa menyebabkan perpecahan bangsa yang lebih permanen. Untuk penelitian selanjutnya, studi ini menyarankan agar mengambil data tweet yang lebih banyak untuk mendapatkan hasil yang lebih beragam. Penelitian serupa juga perlu dilakukan pada kontestasi politik di daerah lain untuk menguji konsistensi hasil dari studi ini.

\section{DAFTAR PUSTAKA}

Abril, E. P. (2016). Unmasking trolls: Political discussion on Twitter during the parliamentary election in Catalonia. Trípodos, 39, 53-69.

Allcott, H., \& Gentzkow, M. (2017). Social media and fake news in the 2016 election.

Aspinall, E., \& Mas' udi, W. (2017). The 2017 Pilkada (local elections) in Indonesia: Clientelism, programmatic politics and social networks. Contemporary Southeast Asia: A Journal of International and Strategic Affairs, 39(3), 417-426.

Barberá, P., \& Rivero, G. (2015). Understanding the Political Representativeness of Twitter Users. Social Science Computer Review, 33(6), 712-729. https://doi. org/10.1177/0894439314558836

Bekir, H., Şahin, H., \& Aydin, R. (2014). University students' perception on woman's place in a family. Procedia - Social and Behavioral Sciences, 143, 14-18. https:// doi.org/10.1016/j.sbspro.2014.07.349

Bode, L. (2017). Closing the gap: Gender parity in political engagement on social media. Information, Communication \& Society, 20(4), 587-603. https://doi.org/10.1080/13 69118X.2016.1202302

Bode, L., \& Dalrymple, K. E. (2016). Politics in 140 characters or less: Campaign communication, network interaction, and political participation on Twitter. Journal of Political Marketing, 15(4), 311-332. https://doi.org/10.1080/15377857.2014.95 9686.

Bryman, A. (2016). Social research methods. Oxford University Press. https://doi. org/10.4135/9781849209939.

Demirhan, K., \& Çakır-Demirhan, D. (2015). Gender and politics: Patriarchal discourse on social media. Public Relations Review, 41(2), 308-310. https://doi.org/10.1016/j. pubrev.2014.11.010.

Eagly, A. H. (1987). Sex differences in social 
behavior: A social-role interpretation. Sex differences in social behavior: A socialrole interpretation.

Eagly, A. H. (1997). Sex differences in social behavior: Comparing social role theory and evolutionary psychology. American Psychologist, 52(12), 1380-1383. https:// doi.org/10.1037/0003-066X.52.12.1380.b.

Eagly, A. H., Eastwick, P. W., \& JohannesenSchmidt, M. (2009). Possible selves in marital roles: The impact of the anticipated division of labor on the mate preferences of women and men. Personality and Social PsychologyBulletin,35(4),403-414.https:// doi.org/10.1177/0146167208329696.

Eagly, A. H., Wood, W., \& Diekma.n, A. B. (2000). Social role thoery of sex differences and similarities: A current appraisal. In The Developmental Social Psychology of Gender (pp. 123-161). Retrieved from https://books.google.com/ $1=$ no\&lr $=\& \mathrm{id}=\mathrm{MFMwjXonRaYC \& pgis}=1$

Gagliardone, I., Gal, D., Alves, T., \& Martinez, G. (2015). Countering online hate speech. UNESCO Series on Internet Freedom. https://doi.org/978-92-3-100105-5.

Gauthier, M., Guille, A., Rico, F., \& Deseille, A. (2015). Text mining and Twitter to analyze British swearing habits. Proceedings of International Conference on Twitter for Research, 28-42. https://doi.org/10.1002/ ejoc.201200111.

Gruzd, A. (2016). Netlytic: Software for automated text and social network analysis. Diakses dari http://netlytic.org

Hardjaloka, L. (2015). Studi dinamika mekanisme pilkada di Indonesia dan perbandingan mekanisme pilkada negara lainnya. JurnalRechtsVinding. Vol 4 No.1 (59-83).

Jayachandran, S. (2015). The roots of gender inequality in developing countries. The Annual Review of Economics, 7, 63-88. https://doi.org/10.1146/annureveconomics-080614-115404.

Juditha, C. (2017). Hatespeech di media online: kasus pilkada DKI Jakarta 2017 hatespeech in online media: Jakarta on election 2017. Jurnal Penelitian Komunikasi Dan Opini Publik, 21(2), 137-151.

Jungherr, A. (2014). Twitter in politics: A comprehensive literature review, 1-90.
Kasmani, M. F., Sabran, R., \& Ramle, N. (2014). Can Twitter be an effective platform for political discourse in Malaysia? A sudy of \#PRU13. Procedia - Social and Behavioral Sciences, 155(October), 348-355. https:// doi.org/10.1016/j.sbspro.2014.10.304.

Kiesler, S., Siegel, J., \& McGuire, T. W. (1984). Social psychological aspects of computermediated communication. American Psychologist, 39(10), 1123-1134. https:// doi.org/10.1037/0003-066X.39.10.1123.

McGregor, S. C., Lawrence, R. G., \& Cardona, A. (2017). Personalization, gender, and social media: Gubernatorial candidates' social media strategies. Information Communication and Society, 20(2), 264-283. https://doi.org/10.1080/136911 8X.2016.1167228.

McNabb, D. E. (2015). Research methods in public administration and nonprofit management: Quantitative and qualitative approaches. 3A.E. Sharpe. https://doi.org/ BB BWL 200 QQ 000 M169.

Metrotvnews.com. (2018). Perang medsos paling panas terjadi di pilgub Sumut. Diakses dari http://video.metrotvnews. com/special-event/GN1A1mVb-perangmedsos-paling-panas-terjadi-di-pilgubsumut.

Neuman, W. L. (2016). Metodologi penelitian sosial: Pendekatan kualitatif dan kuantitatif. Jakarta: Indeks.

Nugraha, F. (2017). Tokoh politik terhadap model pemilukada gubernur. Jurnal Civics, Vol 1, Nol (119-127).

Nulty, P., Theocharis, Y., Popa, S. A., Parnet, O., \& Benoit, K. (2016). Social media and political communication in the 2014 elections to the European Parliament. Electoral studies, 44, 429-444.

Öztürk, N., \& Ayvaz, S. (2018). Sentiment analysis on Twitter: A text mining approach to the Syrian refugee crisis. Telematics and Informatics, 35(1), 136-147. https://doi. org/10.1016/j.tele.2017.10.006.

Parmelee, J. H., Roman, N., Beasley, B., \& Perkins, S. C. (2019). Gender and generational differences in political reporters' interactivity on Twitter. Journalism Studies, 20(2), 232-247.

Preotiuc-Pietro, D., Carpenter, J., Giorgi, S., \& Ungar, L. (2016). Studying the 
dark triad of personality through Twitter Behavior. In Proceedings of the 25th ACM International on Conference on Information and Knowledge Management - CIKM '16 (pp. 761-770). https://doi. org/10.1145/2983323.2983822.

Putra, R. R. (2012). Bentuk dan fungsi kata umpatan pada komunikasi informal di kalangan siswa sma negeri 3 surabaya: kajian sosiolinguistik, 93-105.

Radsch, C. C., \& Khamis, S. (2013). In their own voice: Technologically mediated empowerment and transformation among young Arab women. Feminist Media Studies, 13(5), 881-890. https://doi.org/10 $.1080 / 14680777.2013 .838378$.

Rasywir, E., \& Purwarianti, A. (2015). Eksperimen pada sistem klasifikasi berita hoax berbahasa Indonesia berbasis pembelajaran mesin. Jurnal Cybermatika, 3(2), 1-8. Retrieved from http:// cybermatika.stei.itb.ac.id/ojs/index.php/ cybermatika/article/view/133.

Rosidin, O. (2010). Kajian bentuk kategori dan sumber makian serta alasan penggunaannya oleh mahasiswa. Tesis, UI.

Senova, A. (2016). Literasi media sebagai strategi komunikasi tim sukses relawan pemenangan pemilihan presiden Jokowi JK di Bandung. Jurnal Kajian Komunikasi, 4(2), 142-153. https://doi.org/https://doi. org/10.24198/jkk.v4i2.

Shahheidari, S., Dong, H., \& Daud, M. N. R. B. (2013, July). Twitter sentiment mining: A multi domain analysis. In 2013 Seventh International Conference on Complex, Intelligent, and Software Intensive Systems (pp. 144-149). IEEE.

Wibowo, K. A., \& Mirawati, I. (2013). Realitas politik Indonesia dalam kacamata pengguna Twitter. Jurnal Kajian Komunikasi, 1/1, 11-17.

Williams, S. A., Terras, M. M., \& Warwick, C. (2013). What do people study when they study Twitter? Classifying Twitter related academic papers. Journal of Documentation, 69(3), 384-410.

Zulfikar, W. B., Irfan, M., Alam, C. N., \& Indra, M. (2017). The comparation of text mining with Naive Bayes classifier, nearest neighbor, and decision tree to detect Indonesian swear words on Twitter. In 2017 5th International Conference on Cyber and IT Service Management, CITSM 2017. https://doi.org/10.1109/ CITSM.2017.8089231. 